\author{
頸城（潟町）ガス・油田に括ける原油の性状と地質 \\ との関係について（その 2) \\ 河 井興 三*・戸谷嗣津夫*
}

（昭和44年11月28日受理）

\title{
Some Relationships between Crude Oil Properties and Geology in the Kubiki (Katamachi) Gas and Oil Field, Japan (Part 2)
}

By

Kozo Kawai and Shizuo Totani

\begin{abstract}
We published a paper "Some Relationships between Crude Oil Properties and Geology in the Kubiki (Katamachi) Gas and Oil Field, Japan (Part 1)", which appeared in the Journal of the Japanese Association of Petroleum Technologists, Vol. 35, No. 1. In the paper we pointed out the existence of the correlation between specific gravity of crude oils and reservoir conditions.

This paper now presented here is a sequel of the "Part 1", dealing with the results of gaschromatographic analysis of the crude oils from the Katamachi field.

We sampled the crude oils of the le reservoir from a number of producing wells in the field, and made a gas-chromatographic analysis of lighter cut (lower than $105^{\circ} \mathrm{C}$ ) of the crude oils. The result is shown in Table 2 of the "Part 1". The purposes of the analysis are (1) to determine the degree of evolution of the crude oils, (2) to find out any measure that characterizes the Ie crude, and (3) to presume the direction of lateral migration of the oils. As for the subject (1) we already described in the "Part 1". With regard to the subjects (2) and (3) we adopted Silverman's idea (1965) as working hypotheses. Silverman showed that the ratio of amount of some liquid hydrocarbons to that of other hydrocarbon (excluding benzene) is kept almost constant during secondary migration and accumulation of oil, if the differences in boiling points of these hydrocarbons are small. He also suggested that a trend of decrese or increase of the relative amount of benzene may imply the direction of secondary migration, which is mainly due to the selective adsorption effect of rock-forming minerals.

At first we discuss the subject (2). The ratios of amount of hydrocarbons that Silverman demonstrated are as follows:

(cylcopentane +2 methylpentane +23 dimethylbutane) $/ 3$ methylpentane

(23 dimethylpentane + cyclohexane) / $\mathrm{n}$-heptane

The ratio that characterizes the crude oil and differs from others should at least have smaller variance and bear no correlation to any other factors, i.e. specific gravity of crude oil, reservoir conditions and so on. We tested the above ratios for the crudes from the Katamachi Ie reservoir, but no satisfactory results were obtained. We further tested many other ratios that Silverman had not shown, but we could not find out suitable one to the crude oil. In the course of this study we found out that some ratios have correlationship with the specific gravity of the crude oils (Figures 10 and 11). We cannot explain the reason, but we presume the alteration of crude oils by formation water which is of low salinity and has a considerable amount of sulfate ion. Furthermore, we can recognize the tendency that a number of ratios in the east side of $d-d^{\prime}$ ' fault are different from those in the west side of the $d-d$ ' fault (Figures 13 and 14).

Next, we deal with the subject (3). We adopted benzene/n-heptane ratio as a measure of the relative amount of benzene. As shown in Figures 12, 13 and 14, in the west of $d-d$ ' fault the measure increases in the down-dip direction, whereas in the east of the $d$-d fault the tendency is just opposite, that is, the measure increases in the up-dip direction. This fact implies that in the west of
\end{abstract}

* 東京大学工学部資源開発工学科 
$d-d$ ' fault oil probably migrated from south to north in concord with the present structure, but in the east of $d$-d' fault it probably migrated north to south, i. e. from the place near the culmination of the Katamachi structure at precent to the south wing of the structure at present. Sulfer content of crude oils, though the data are not sufficient, shows similar tendency. In the east of $d \cdot d$ ' fault and near the culmination of the Katamachi structure, a considerable part of the Ie reservoir produces neither oil nor gas; saturated with water. These facts seem to support our opinion. There are many minor faults in the Katamachi structure (Figure 2) but the faults except $d$ - $d$ ' fault do not affect the crude oil properties. The $d$-d' fault is also minor one, however, due to the above-mentioned facts, there is the possibility that only $d$-d' fault was active or growing during the time of secondary migration and accumulation of oil, and that in the east of $d \cdot d^{\prime}$ fault more oil may be expected on the south of the developed area.

In conclusion we lay stress on the importance of interpretation of geochemical data taking fully reservoir conditions into account. Geochemical data are useful for understanding the reservoir conditions and vice versa. A correct interpretation may suggest the area to be developed.

\section{緒 言}

筆者らは前報（石沾技術協会誌，35巻，1 号）におい て, 頸城原油についての試験・分析の項目・方法および その結果を報告し，さらに油層状態との関係について篗 者らの所見を述べた。すなわち，筆者らの主対象とした 本ガス・油田における Ie 泎層の油では，原油比重が初 産水油比および油層層厚などと相関関係がみられ，とく に同一構造・同一油層にもかかわらず, $\mathrm{d}$ - $\mathrm{d}^{\prime}$ 断層の東側 ではその関係がよく現われている。一方，その断層の西 側では,部分的にそれらとの関係がみられるが，一般に余 り明瞭ではない。こうした関係を説明するために筆者ら は模型的断面図（第7図）によってその所見を述べた。 また, 本ガス・油田における油の試験・分析結果から, 進化度の低い油であることもわかった。

本稿に打いては，ガスクロマト分析で得た成分につい て, S. R. Silverman（1965）が提示した“低級炭化水素 成分のうちで近似した沸点をもつ特定の成分 (Benzene を除く）の量比は，油の 2 次移動時において不変であ る”という考えをここに追試すると同時に゙，彼が行なわ なかった種々の点を検討してみた。それらについての関 係と筆者らの所見を、いくつかの例を示して報告したい。

\section{成分の量比と他の要素との関係}

前報に执いてすでに述べたように，同一油層の油でも 成分ごとに差のあることが認められている(第 2 表)。 Silverman は, これら成分が油の 2 次移動および集積の 過程において，量的な変動はあっても，ある特定の成分 の量比は，たとえ相 (phase) が変っても変化がないとい うことを $2 ， 3$ の量比を示して説明している。この考え は原則的には全く合理的である。彼の示した成分の量比 を改めて示せば，次のようなものである゙。

* 炭化水素の略称は前報の表 2 を参照されたい。
(C Pent. +2 MPent +23 DMB) /3 MPent

(23 DMP $+\mathrm{C}$ Hex. $) / \mathrm{n}-$ Hept.

筆者らは，まずこれら成分の量比について検討を行な ってみた。しかし Ie 油層の油には, 彼が報告したよう な結果は得られず，むしろ大きなばらつきのあることが 認められた。彼の考えを作業仮説とした筆者らには，こ の結果は予期に反したものである。したがって彼の示し た上記の成分の量比に沶いて，篗者らはこれら量比の分 子にとられた成分と，分母にとられた成分とのそれぞれ のもつ沸点に, 差がありすぎる（前者の量比の沸点差は $14.02^{\circ} \mathrm{C}$ ，後者は同じく $\left.17.69^{\circ} \mathrm{C}\right)$ のではないかと考え た。そこでなるべく近似した沸点をもつ成分についての 量比をとって，同じように検討を行なったのであるが， やはり満足すべき結果は得られなかった。かくして原油 を特徴づける不変の成分量比を見出すことができなかっ た。しかもなお，こうした多くの成分の量比の中には, 原油比重・初産水油比打よび油層層厚などと関連をもつ ものが多くみられたので，それらの中からいくつかの量 比について紹介したい。

まず，原油比重と関係をもつ量比の中では，とくに第 10図および第11図に示すようなものがある。第10図にお ける量比は分子扰よび分目にとられた成分が炭素数 6 の もので，分母は正へキサン，分子はそれの異性体であ

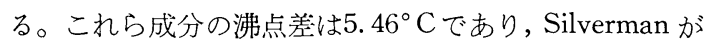
採用したものよりはずっと近似した沸点をもつ量比であ る。プロットされたこれら量比は, 原油比重にして 0.2 前 後の幅はあるが，よく負の相関関係を示している。一方， 第11図に打ける量比は分子および分母にとった成分が炭 素数 7 のもので, 分子には正へプタンの異性体である 223 $\mathrm{TMB}$ ，分母には正へプタンを含め $22 \mathrm{DMP}, 24 \mathrm{DMP}$, $2 \mathrm{MHex}$ ，3 MHex を加えたものの量比である。その 沸点差は第10図の量比よりも，また Silvermanの示した

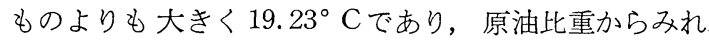


Figure 10 Relation between Specific Gravity of Crude Oil and 3 methylpentane / n-Hexane.

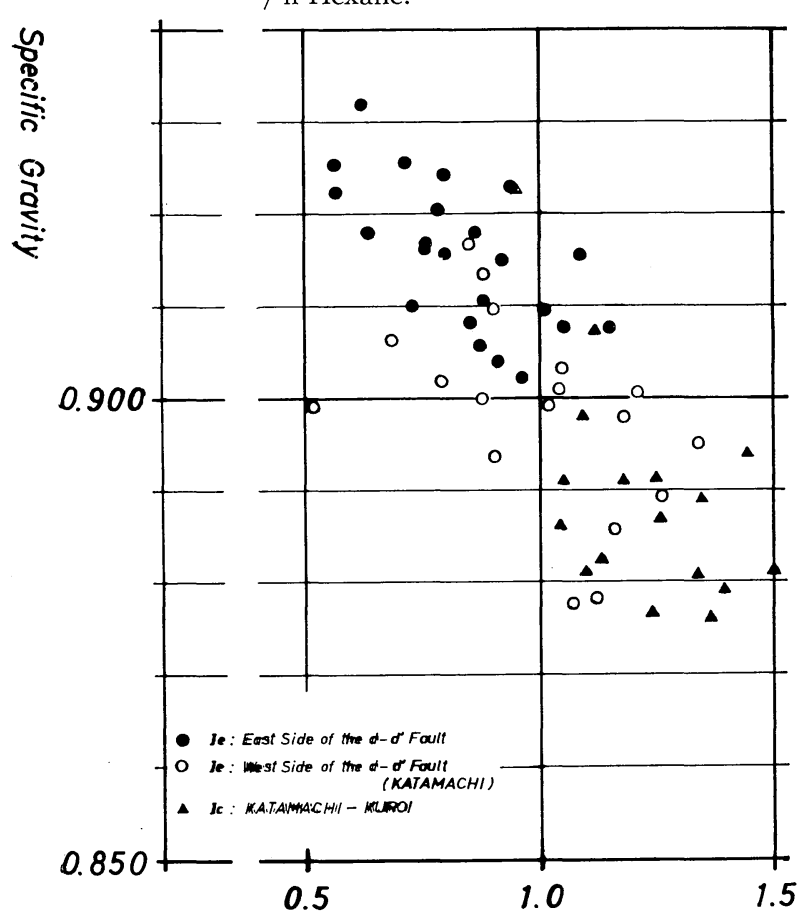

Figure 11 Relation between Specific Gravity of Crude Oil and 223 trimethylbutane $/ C_{7} *$

$C_{7}{ }^{*}=22 \mathrm{DMP}+24 \mathrm{DMP}+2 \mathrm{MHex}+3 \mathrm{MHex}+\mathrm{n}-\mathrm{Hept}$.

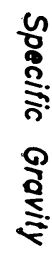

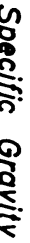

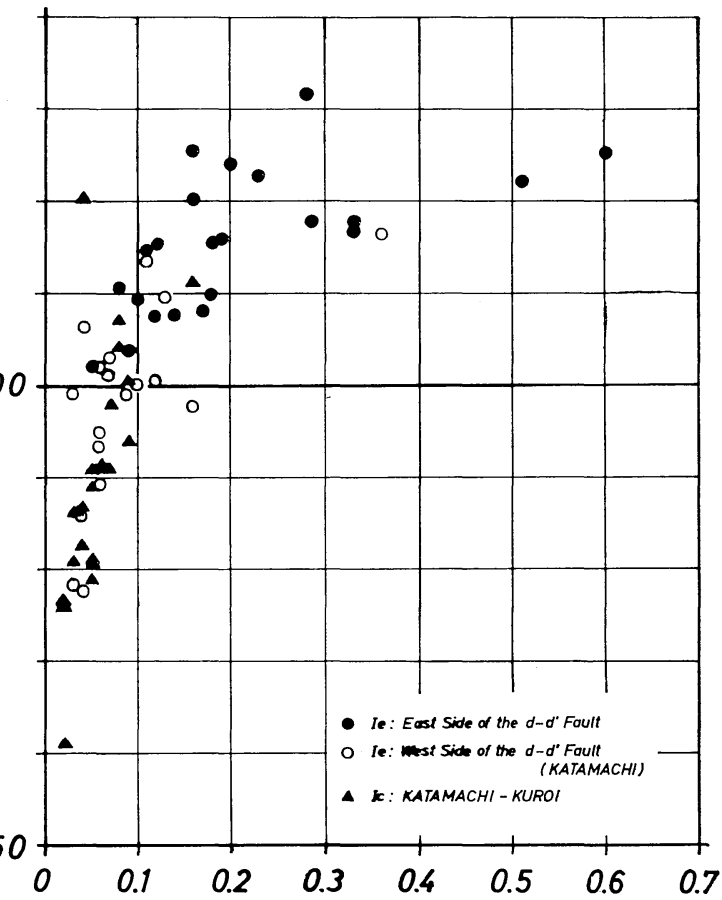

ば，前者よりその量比に大きな差があるにも かかわらず，総体的な傾向はよく比重と正相 関関係を示している。なおこの $223 \mathrm{TMB}$ は前報の第 2 表を参照されるとわかるのであ るが，その相対量が他の成分の相対量に比し て大きな変動を有することが認められる (Benzene を除いて)。

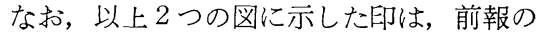
原油比重分布（第5図）などに示した $\mathrm{d}-\mathrm{d}^{\prime}$ 断層の東側のもの (黑丸印) と西側のもの (白丸印) とに区別して，プロットしたもの である。また，参考までに Ie 油層のものを 三角形印として示しておいたが，これら量比 と原油比重との関係からも, $\mathrm{d}-\mathrm{d}^{\prime}$ 断層の東 側と西側とで異なった分布をしていることが 認められよう。これはすでに前報でも述へたた ように，東側と西側との原油比重の差異が油 層状態の差異として，ここにも現われている 女のと考えられる。相対量と初産水油比およ び油層層厚との関係についても，同じような 傾向がみられているが，原油比重との関係ほ ど明らかではない。

筆者らの主対象とした Ie 油層における坑 井は，前報の第 1 表に示すように潟町構造だ けで39坑井あり，それら全部について検討す ることはデータの欠如もあって行なえなかっ た。そこで,第12図に示すような坑井を $\mathrm{d}-\mathrm{d}^{\prime}$ 断層を境として，東側と西側とに区別して選 び，さらに構造の下部から上部へ点線に沿っ た順序に従って坑井を並へ，それぞれの坑井 からの油の成分の量比を棒グラフによって表 現したものが第13図と第14図である。

これらの図において，原油比重・油層層厚 および初産水油比などの相互関係について は，すでに前報の原油比重の項で筆者らの考 えを述へててるので改めて説明はしないが， 第13図，第14図に選んだ坑井は第12図のほぼ 断面線上にあるもので，これらの坑井からの データでも，筆者らが前報で述べた考えを裏 づけような結果がみられる。そうした傾向 は以下に述べる成分量比にも関連をもってい る。

第13図の $\mathrm{a}$ と第14図の $\mathrm{a}^{\prime}$ は, Silverman が 採用した成分の量比であるが，aは原油比 重・油層層厭および初産水油比とは全く無関 係で, むしろ構造の頂部へ向って小さくな 
Figure 12 Index Map for Figs. 13 and 14.

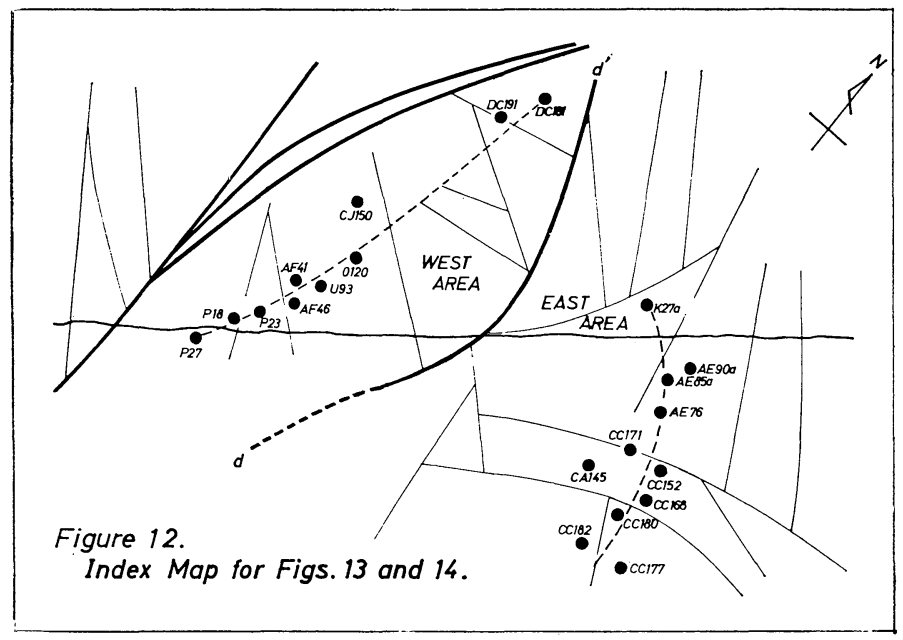

り，その変動も大きい。a $\mathrm{a}^{\prime}$ は DC-191，P-32 の 2 坑井を 除汁ばほぼ同量比にあるが，細かくみれば原油比重の変 化に類似しているようである。したがって， Silverman が提晿したこの成分の量比は，ここでは原油を特徵づけ る不変の成分量比とはなりえない。

第13図の b と第14図の b' は, 前述したように原油比重 とよく負の関係を示す成分量比である。bではその傾向 性がよくみられるが, 油層層厚および初産水油比とも僅 かながら前者に正，後者に負の関係を有するように思わ れる。一方， b'では明膫ではないが，大局的にみて構造 の頂部に近いほどこの值が大きくなっているようであ る。細かくみれば構造の翼部に近い P-32, P-18, P-27な どの坑井では, 油層層厚・原油比重と正の関係があるよ
うである。この量比も不変の成分量比とはなりえない。 第13図の $\mathrm{c}$ と第14図の $\mathrm{c}^{\prime}$ は, 原油比重と正相関関係を もっているものである(第11図)。cではその傾向がみら れるが，構造の頂部へ向って減少する傾向もある。 $\mathrm{c}^{\prime}$ で もそれほどはっきりしないが，原油比重との相関はある

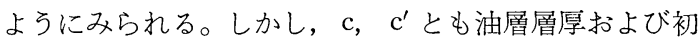
産水油比とはあまり関連性はないようである。

第13図の $\mathrm{d}$ と第14図の $\mathrm{d}^{\prime}$ は, その沸点差は $1.80^{\circ} \mathrm{C}$ で，これら図にあげた成分の量比の中では最も近似した 沸点をもつ成分である。d では原油比重・初産水油比揖 よび油層層厚とはほとんど関係はないようであるが，構 造に対してはその頂部に向って僅かながら溸増している ように見受けられる。 $\mathrm{d}^{\prime}$ では原油比重・初産水油比およ

Figure 13 Various Properties of Crude Oils along the Dashed Line in Fig. 12 to the East of the $d-d^{\prime}$ Fault.

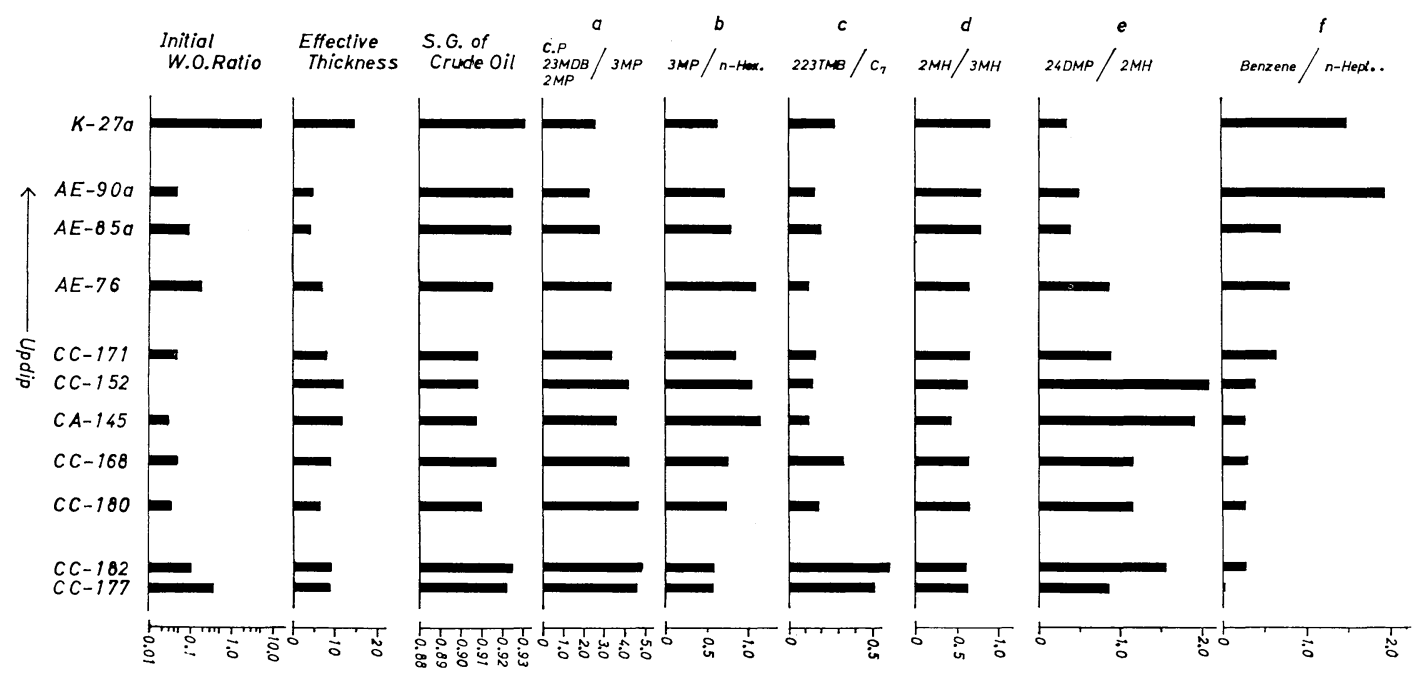


Figure 14 Various Properties of Crude Oils along the Dashed Line in Fig. 12 to the West of the $d-d^{\prime}$ Fault.

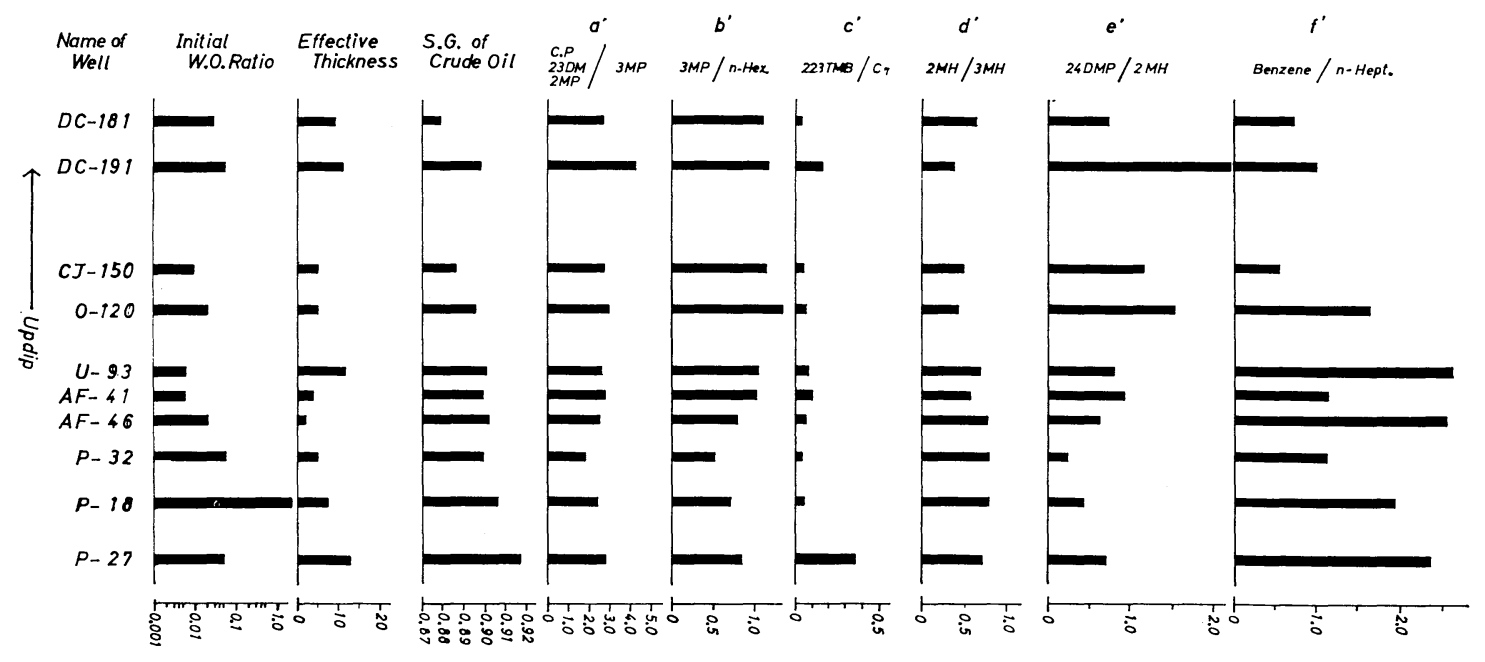

び油層層㕌とほぼ負の関係を示しているようにみられ る。この量比もその変動が $\mathrm{c} ， \mathrm{c}^{\prime}$ ほどではないが, Martin et al. (1963) の示す安定順位の上で上位にあり ながら，その量比に差があるように思われる。

第13図の e と第14図の $\mathrm{e}^{\prime}$ は, 沸点差が $9.55^{\circ} \mathrm{C}$ である が，両者とも非常に変動が大きく不変の成分量比とはな りえない。e ではほぼ原油比重・初産水油此と負, 油層 層厚とは僅かではあるが正の関係がみられ，しかも大局 的に構造の頂部へ向って減少の傾向がある。 $\mathrm{e}^{\prime}$ では e の 場合とほぼ逆であって, 原油比重が大局的に構造の頂部 へ減少するのに対して，この量比は逆に頂部へ向って増 加している。

以上述べた成分の量比は，いずれをとっても原油比重 などと相関があったり，あるいはばらつきが大きかった りして，原油を特徴づける成分量比とはなりえない。そ して多くの成分量比は $\mathrm{d}-\mathrm{d}^{\prime}$ 断層の東側と西側とで異な った分布傾向を示し，他の断層には影響されていないよ うにみえる。

最後に，第13図の $\mathrm{f}$ と第14図の $\mathrm{f}^{\prime}$ につて述べる。 Silverman も述べているように, Benzene は泊の 2 次移 動時に扎いて岩石表面の水膜界面に著しく吸着された り，あるいは一部が水に溶解したりするために，油の移 動方向にその含有量が減少するといわている。こうした 考えからすれば，今この $\mathrm{f} と \mathrm{f}^{\prime}$ とではその減少傾向が全 く逆であることは注目に值する。とくに $\mathrm{d}-\mathrm{d}^{\prime}$ 断層の東 側のfでは, 現在の地質構造とは逆にあたかも現在の構 造の頂部から翼部へ向って, 油の移動があったようにみ られ, 同一構造・同一油層でもこの $\mathrm{d}-\mathrm{d}^{\prime}$ 断層（この断
層は大断層ではなく minor fault である) の両側で, 油 の移動方向が逆転していることになる。

な拝，最近硫黄分の測定を行なったが，手持ちの試料 も少なくはっきりしたことはいえないが, $\mathrm{d}-\mathrm{d}^{\prime}$ 断層の 東側では，上記の Benzene/n-Hept. の量比の減少傾向 に類似しているようである。その最大值は $0.20 \%$ （重 量）で，最小值は $0.14 \%$ であった。一方，西側では0.16 〜 $0.18 \%$ で東側ほどの傾向はみられなかった。

上記したように成分の量比においても， $\mathrm{d}$ - $\mathrm{d}^{\prime}$ 断層を 境とした東側と西側では，異なった傾向または変化を示 している。これは前報にも述べたように，原油比重が初 産水油比および油層層厚と関係をもつような傾向に加え て，成分の量比も類似しているためと考えられる。こう した関係および傾向が同一構造・同一油層にみられるこ とは，本溜層の油層状態によって油の成分も影響を受け るものと思われ，そのような影響の著しい地域は $\mathrm{d}-\mathrm{d}$ ， 断層の東側であるう。

な掞,こうした影響の一因として，本油層の油田水の 壏分濃度打よび硫酸イオン濃度が考えられる。前者は一 般に低濃度であり, 後者は逆に高濃度を示し, 局部的に は著しく高い值をもっている。このような水の油の成分 への影響も考えられ, 平塚 (1963) のいう水蝕があった ものと思われる。その影響を受けたものとすれば，やは り前報の第 6 図に示されるように, 初産水油比の大きい $\mathrm{d}$ - $\mathrm{d}^{\prime}$ 断層の東側の方が西側より大きかったのではない かと思われる。 


\section{結}

\section{論}

筆者らは，Silverman (1965) の提示した油の低級炭化 水素成分のうちで, 沸点の近似したある特定の成分の量 比は, 油の 2 次移動・集積の過程に沶いて変化しない, という考えを作業仮説として本研究を進妨た。しか し, 彼の提示した成分の量比はもちろんのこと, 筆者ら が試みた多くの量比でも，原油を特徴づける一定不変の 成分量比は得られなかった。したがって，彼の提示した 成分の量比は油の 2 次的な要因，すなわち油層状態によ る油質の変化や水蝕というものが考虑されていなかった か，または考虑しなくとも油層状態が一様であったか， のいずれかであろうと考える。今後, こうした要因をも 考虑して，本ガス・油田のような複雑な地質条件をもた ない, もっと単純な泪層をもつ油田について行なえば, より明確な結果が得られるのではないかと考える。

な打，本ガス・油田における油の成分が，原油比重・ 初産水油比抢よび油層層厚などに関係をもっていること などから，炭化水素成分の水に対する溶解度や熱に対す る安定度をも充分に考慮して，これらにも影響を受けな い成分を探索することが原油を特徴づける上に望ましい と考える。

最後に, 前報と本稿を通じて, 本ガス・油晒について の筆者らの所見を要約すれば，次の通りである。

(1) 頸城原油は総じて Martin et al. (1963)の指摘し た進化度の低い原油の特徵をもっている。

(2) 犀潟駅付近を通る南北性の $\mathrm{d}-\mathrm{d}^{\prime}$ 断層の東側で は, 原油比重は初産水油比の大きい所で高く，かつその 部分は油層の砂の薄い部分にほぼ一致するが,この傾向 はこの断層の西側では余り明らかではない。

なお，この断層は決して大断層ではなく, minor fault である。

(3) 種々の 2 成分の量比は, Benzene/n-Hept. などの 比を除き，Silverman (1965) が示したような油の 2 次移 動時に不変の成分の量比は, 本ガス・油田では未だ見出 し得ない。

(4) 2 成分の量比の中には, 原油比重・初産水油比打 よび油層層厚と相関するものが少なくない。とくに $\mathrm{d}$ - $\mathrm{d}^{\prime}$ 断層の東側ではこの傾向が著しい。これはその一 因として平塚（1963）のいう水蝕のためであろう。

(5) Benzene/n-Hept. の量比などは, d-- $\mathrm{d}^{\prime}$ 断層の雨
側でその分布傾向が逆転している。この比が油の 2 次移 動につれて減少するとすれば，この断層の両側で油の 2 次移動の方向が逆であったことになる。とくに $\mathrm{d}-\mathrm{d}^{\prime}$ 断 層の東側では, 油の 2 次移動つ方向は現在の地質構造と は全く逆であったと考えられるので， down-dip 方向に 探鉱を進めて行くべきであろう。

(6) 以上(1)〜 (5)から考えれば，この断層の両側で油層 状態または油層形成時の状態が異なり，多くの小断層の うちでこの $\mathrm{d}$ - $\mathrm{d}^{\prime}$ 断層だけが油の集積時に，すでに形成 もしくは活動していた可能性がある。

\section{参 考 文 献}

1）相場婷一 (1963)：頸城ガス由の地質と鉱床，石 技誌, 第 28 巻, 第 2 号, 43 頁

2) Hodgson, G. W. and Baker, B. I. (1959): Geochemical Aspects of Petroleum Migration in Pembina, Redwater, Joffre, and Lloydminster Oil Fields of Alberta and Saskatehewan, Canada, Bull. A. A. P. G., Vol. 43, No. 2, p. 311

3）平塚隆治 (1963)：秋田地域産原油の油質的考 察，石技誌，第29巻，第 7 号, 350頁

4）井上重一，相場惇一 (1960)：頸城ガス田，石油 誌, 第 3 巻, 第 3 号, 219頁

5) Martin, R. L. et al. (1963) : Composition of Crude Oils by Gas Chromatography: Geological Significance of Hydrocarbon Distribution, 6th World Petroleum Congress, Frankfurt Am Main. 第 6 回世界石油会議重要論文集 (下巻), 石油評論 社, 38頁

6) Hunt, J. M. (1953): Composition of Crude Oil and Its Relation to Stratigraphy in Wyoming, Bull. A. A. P. G., Vol. 37, No. 8, p. 1837

7) Hunt, J. M. and Forsman, J. P. (1957) : Relation of Crude Oil Composition to Stratigraphy in the Wind River Basin, Wyoming Geological Association Guid-Book, p. 105

8) 相場惊一 (1965): 頸城ガス田, 石油誌, 第 8 巻, 第 7 号, 2 頁

9) Hodgson, G. W. (1954) : Vanadium, Nickel, and Iron Trace Metals in Crude Oils of Western Canada, Bull. A. A. P. G., Vol. 38, No. 12, p. 2537

10) Silverman, S. R. (1965): Migration and Segregation of Oil and Gas, Fluids in Subsurface Environments., A. A. P. G., Tulsa, Oklahoma, U. S. A., p. 53, 加藤正和訳, 油抢よびガスの 移動と分離，石技誌，第30巻，第 3 号，136頁 